action as simple as picking up a pencil demands the complex processing of information not just from our eyes, but from sense organs in our muscles, skin and joints, from the vestibular receptors that tell us about the motion and attitude of our head relative to gravity, and from the stored expectations that we have of the way the world is structured.

To a very large extent, this integration of various kinds of information must be learnt: unlike a surveyor's theodolite, our senses do not come to us ready-calibrated in degrees and minutes of arc, but must be scaled by our own brain through its experience of the way in which one kind of sensation tends to be correlated with another. If we wear prisms that deviate our sight to one side, though at first we reach out for visual objects at the wrong place, after only a few trials our brain adjusts itself to the new situation and no errors are made. This aspect of sensory location has stimulated a great deal of interest over the past few years, for it enables one to make attractively quantitative measurements of the learning processes involved. The advantage of studying sensorimotor coordination rather than perception is that we then work with a system with a clearly defined output as well as input; in the latter case there must always be some doubt as to the nature of whatever it is that is doing the perceiving.

Behind a deceptively modest title, Human Visual Orientation hides a wealth of detailed and remarkably up-to-date information about nearly all aspects of this very wide subject. Particularly welcome, in a field where slipshod terminology can easily lead to tangled confusion (how, for example, does one rigorously define the direction of gaze?), are the author's succinct definitions of technical terms, and his clear and intelligent reviews of salient facts in an area in which many important observations date back to the nineteenth century. Many topics which the title of the book might not lead one to expect - the neurophysiology of eye movements, for one - are summarized with equal clarity and expertise.

In other respects, however, the author has perhaps been too modest in his aims: his explicit omission of motion perception and other dynamic aspects of orientation, and perhaps especially his suspicion of model-building and his reluctance to synthesize and integrate on more than a moderate scale, may leave some readers unsatisfied. But this does not detract significantly from what is otherwise a firstrate book, a richly-veined mine of information that will undoubtedly become a standard work of reference and provide much to ponder upon for many years.

Roger Carpenter is a Lecturer in Physiology at the University of Cambridge. He is author of Neurophysiology, shortly to be published by Edward Arnold, and of Movements of the Eyes (Pion, 1977).

\section{To whom does the United States belong?}

\section{Lynton K. Caldwell}

The Land Use Policy Debate in the United States. Edited by Judith I. de Neufville. Pp.269. ISBN 0-306-40718-3. (Plenum: 1981.) $\$ 29.50, £ 18.59$.

TO UNDERSTAND the land use policy debate in the United States one must first recollect its historical context. During the colonial era, and for decades thereafter, settlers were drawn to the New World by the prospect of free land unburdened by the feudal legacy of taxes and servitudes. And whereas general English common law regarding ownership and tenancy of land was brought to North America, specific restrictions were left behind. Moreover the early years of colonization occurred at a time when English landowners were shaking off feudal exactions. In any event, controls by government were largely unenforceable on the frontiers of settlement. Then, as public authority and jurisdiction were extended to unappropriated lands, the guiding object of public policy was to move ownership as rapidly as possible into private hands.

For a century after independence, speculation in the purchase and sale of public lands was one of the principal roads to wealth in the United States. And the most respected figures in public life, not excepting George Washington himself, did not hesitate to engage in it. The privatization of land was carried further in North America than perhaps in any other country in the modern world. Attempts to impose even minimal controls on the uses of land have not come easily. In 1970 the Senate of the United States considered a National Land Use Planning Act, which was intended to encourage states and localities to adopt forms of democratic planning that would avoid at least the worst conflicts and demonstrable misuses of land. Endorsed by President Nixon, this measure passed the Senate on three occasions but never reached the floor of the House of Representatives, being blocked by a combination of land speculators, developers, farmers and ordinary citizens who feared that the government was about to take away the right to do as they pleased with the land that they owned.

Against this background, one may better understand the 20 essays that make up this book. They evolved out of a colloquium held in 1977 under the sponsorship of the Lincoln Institute of Land Policy at Cambridge, Massachusetts. In view of the long history of frustration in land use planning in the United States, it was appropriate that the focus of the colloquium was on latent values in land use policy. It should be apparent that a significant measure of change in popular understanding and attitude will have to occur before rational land use policy will become effective in the United States.

The scope of the colloquium, and the book, includes considerations of land use as affected by economic, social and environmental policy, the role of markets, the law and public participation. Finally, the authors raise the possibility of a new

\section{The geologist's wife}

TO HER HUSBAND SETTING OFF UPON AN EXCURSION

Adieu then, my dear, to the Highlands you go,

Geology calls you, you must not say no;

Alone in your absence I cannot but mourn,

And yet it were selfish to wish your return.

No, come not until you have searched through the gneiss,

And marked all the smoothings produced by the ice;

O'er granite-filled chinks felt Huttonian joy,

And measured the parallel roads of Glenroy.

And if, in your wanderings, you chance to be led

To Ross-shire or Moray, to see the Old Red,

Oh still, as its mail-covered fishes you view,

Remember the colour is love's proper hue.

Such being your feelings, I'll care not although

You're gone from my side - for a fortnight or so;

But know, if much longer you leave me alone,

You may find, coming back you have two wives of stone!

These verses, four of the eight in The Geologist's Wife - written by the anonymous but evidently love-lorn "Susan" in 1847 - are taken from The Poetry of Geology, recently published by George Allen \& Unwin. The anthology is edited by Robert M. Hazen and costs $£ 4.95, \$ 9.95$. 